\title{
Mariusz Filip
}

mfilip@amu.edu.pl

Instytut Etnologii i Antropologii Kulturowej

Uniwersytet im. Adama Mickiewicza w Poznaniu

\section{RODZIMOWIERSTWO A STRAIGHT EDGE. BUDOWANIE ARYJSKIEGO DUCHA W SKRAJNIE PRAWICOWYM NEOPOGAŃSTWIE SLOWIAŃSKIM}

\section{Native Faith and straight edge: Building the Aryan spirit in the extreme right-wing Slavic Neopaganism}

Streszczenie: Neopogaństwo nie jest ,religią wolności”. W obrębie ruchu istnieją ścieżki, które ufundowane są na zasadach porządku, dyscypliny i ograniczeń, a szczególnie dotyczy to skrajnie prawicowego neopogaństwa. Z uwagi na to, że w dużej mierze idee te znajdują swój wyraz na gruncie jedzenia i picia, pewne analogie $\mathrm{z}$ lewicową subkulturą straight edge nasuwają się same. Podobieństwo to, wobec historycznych związków między subkulturami skinhead i punk, nie jest szczególnie zaskakujące, niemniej skłania do zgłębienia znaczenia stylu życia straight edge dla skrajnie prawicowych neopogan. Koncentrując się na Zakonie Zadrugi „Północny Wilk”, działającym na terenie Polski, ukażę, że straight edge służy nie tyle budowaniu (czystego) ciała, co raczej ducha. Silne, zdrowe ciało jest nieodzowne w odgrywaniu roli aryjskiego wojownika, ale to nie wyjaśnia istnienia ograniczeń dotyczących spożywania alkoholu czy zakazów zażywania narkotyków i krzyżowania się z przedstawicielami innych ras. Czystość pojmowana jest w kategoriach duchowych, a straight edge służy utrzymywaniu granic symbolicznych wobec innych skrajnie prawicowych neopogan.

Słowa kluczowe: straight edge, neopogaństwo, skrajna prawica, ciało, duch, jedzenie, ograniczenia żywieniowe, używki.

Abstract: Neopaganism is not simply a 'religion of freedom'. There are paths where order, discipline and restriction are foundations of religious 
practice and this is particularly true regarding the extreme right-wing Neopaganism. Since these ideas manifest themselves largely in the field of food and drink, it seems sound to draw an analogy with the left-wing straight edge subculture. Due to relation between skinhead and punk subcultures this similarity may not be surprising, however it provokes to explore the meaning of straight edge lifestyle for extreme right-wing Neopagans. Focusing on the Order of Zadruga 'Northern Wolf' from Poland, I will demonstrate that straight edge way of life serve not the purpose of building the body but rather the spirit. The strong, healthy body is important for executing the role of Aryan warrior but it does not explain neither why alcohol and drug prohibition goes hand in hand with anti-miscegenation rules nor their significance. Cleanness is understood in spiritual terms and straight edge is largely used for maintaining the symbolic boundaries against other extreme right-wing Neopagans.

Keywords: straight edge, Neopaganism, extreme right-wing, body, spirit, food, food restrictions, stimulants. 
Rodzimowierstwo a straight edge: budowanie aryjskiego ducha...

Neopogaństwo to głęboko zróżnicowany nowy ruch religijny, rozwijający się przynajmniej od okresu międzywojnia, mający na celu rewitalizację pogańskiej duchowości - przyjmując za punkt wyjścia bądź różnorakie „praktyki magiczne” (czarownictwo, druidyzm, neoszamanizm), bądź różnego rodzaju „etniczności” (germańskie, celtyckie, słowiańskie itd.) (np. Okraska 2001) - a tym samym zorientowany przeciwko chrześcijaństwu, pojmowanemu jako religia opresyjna. Odrzucając zdecydowanie ideę „przymusu”, neopoganie postrzegają swoją religię jako „religię wolności”, którą charakteryzuje wolność wyboru określonej „ścieżki”, wolność sposobu praktykowania wiary i wolność religijna. Ideały te nie zawsze przekładają się jednak na praktykę: między nurtami neopogaństwa etnicznego, coraz częściej nazywanego emicznie rodzimowierstwem (Simpson, Filip 2013), a jawnie anty-etnicznymi formami neopogaństwa, czy też między jego lewicowym i prawicowym skrzydłem, nie zawsze łatwo przecież o wzajemne poszanowanie odmienności. Nierzadko też podstawę neopogańskiej religijności stanowi porządek, dyscyplina i różnorakie ograniczenia. Twierdzenie to wydaje się szczególnie prawdziwe wobec skrajnie prawicowych (nacjonalistycznych i rasistowskich) ${ }^{1}$ form neopogaństwa, ale nie zapominajmy, że i rytuały inicjacyjne wicca (jedna z form czarownictwa) cechuje nierówność statusu, hierarchia i dyscyplina. Nie ulega zatem wątpliwości, że i w przypadku neopogaństwa mamy do czynienia z procesami budowania tożsamości poprzez rodzaj zniewolenia, co zresztą w świetle koncepcji ujarzmiania Michela Foucaulta (1998) nie powinno zaskakiwać nikogo.

Pożywienie stanowi jeden z podstawowych aspektów kultury, zasadne jest więc oczekiwanie, że takowa dyscyplina będzie manifestować się niezwykle wyraźnie w sferze jedzenia i picia. Praktyki żywieniowe skrajnie prawicowego Zakonu Zadrugi „Północny Wilk” (ZZPW), jednej z najbardziej znaczących grup na gruncie neopogaństwa słowiańskiego w Polsce (dalej: „rodzimowierstwo”)', wskazują na specyficzne przesunięcie

${ }^{1}$ Pojęć „,rasizm” czy „nacjonalizm”, a także „narodowy socjalizm” używam w sposób opisowy i pozbawiony wartościowania. W wielu przypadkach określenia te stanowią bezpośrednie odzwierciedlenie dyskursu grup (lub osób) reprezentujących ten nurt neopogaństwa.

2 Rodzimowierstwo stanowi przedmiot badań od blisko trzydziestu lat, co przekłada się na dość pokaźną literaturę (np. Simpson 2000), której nie ma potrzeby tutaj streszczać. Lewicowa bądź prawicowa orientacja polityczna rodzimowierców (zrzeszonych bądź nie) stanowi najważniejszą linię podziału tego środowiska (Filip 2011), pozostając $\mathrm{w}$ bezpośrednim związku $\mathrm{z}$ teologią dwóch wiodących związków religijnych: 
restrykcji ze sfery pożywienia na sferę używek. Intelektualne źródło inspiracji (nie tylko) w tym zakresie stanowią postulaty eugeniczne narodowego socjalizmu ${ }^{3}$, swoją uwagę chciałbym jednak skupić na wpływie mniej świadomym, a więc na generatywnym wymiarze organizacji społecznej (Barth 1966).

W istocie podejście ZZPW do używek bliskie jest pierwotnie lewicowej subkulturze straight edge ( $\mathrm{sXe}$ ), która wyłoniła się w ramach hardcore punku na początku lat 80., samodefiniując się poprzez odrzucenie alkoholu, papierosów i narkotyków oraz przypadkowego seksu, później także (w mniejszym stopniu) mięsa (Wood 1999, Williams, Copes 2005, Haenfler 2006, Kuhn 2010). Na gruncie ruchów prawicowych werbalizacja wpływu subkultury sXe pod postacią nazwy wiąże się z oderwaniem pojęcia od kontekstu historycznego (a więc jego upotoczenienie) (np. Ćwiek 2017, Godziński 2018), jednak przez ZZPW wpływ ten nigdy nie był wyrażany samą nazwą ${ }^{4}$, lecz stanowił wyraz złożonych relacji między młodzieżowymi subkulturami skinhead i punk: zarówno globalno-historycznymi (np. Brown 2004), jak i lokalnymi ${ }^{5}$. Formy sXe rozwijające się w ramach ruchów skrajnie prawicowych nie doczekały się do tej pory należytej analizy (zob. jednak Wood 1999: 134, 138-139, 141), aczkolwiek ich istnienie nie umyka uwadze badaczy skrajnej prawicy (np. Shekhovtsov 2012: 287, Kürti 2012: 121, Likhachev 2013: 66-67) i neopogaństwa (Aitamurto, Gaidukov 2013: 157, Aitamurto 2015: 1667-1668). Nie sposób dłużej ignorować kwestii wpływu tożsamości narodowych, religijnych itd. na ruch sXe, zwłaszcza w świetle przekonań o polskim

Rodzimego Kościoła Polskiego i Rodzimej Wiary, która odwołuje się do dorobku przedwojennego Ruchu Nacjonalistów Polskich ZADRUGA (np. Potrzebowski 2016) i z którą stowarzyszony pozostaje właśnie ZZPW. Rzeczona grupa stanowi przedmiot mojego nieustającego zainteresowania od 2004 roku (Filip 2008, 2009, 2011, 2014, zob. też Strutyński 2005, 2008).

${ }^{3}$ Nie licząc Zadrugi oddziaływanie polskich organizacji patriotycznych na ruch neopogański jest znikome, co da się wytłumaczyć ich wspieraniem się na wartościach chrześcijańskich czy nawet hinduistycznych, czego najlepszym przykładem jest stowarzyszenie Eleusis Wincenta Lutosławskiego.

${ }^{4}$ Należy tu podkreślić słabe ustrukturyzowanie lewicowego sXe oraz dość częstą praktykę nie odnoszenia do siebie kategorii sXe przez jego członków (Williams, Copes 2005, por. Fine, Kleinman 1979, Widdicombe 1998).

${ }^{5}$ Różne strategie rozwiązania napięcia pomiędzy orientacją lewicową i prawicową dowodzą, że „ludzie mogą wykorzystywać obce wpływy strukturalne tak, aby służyły one ich własnym miejscowym systemom symbolicznym, i w ten sposób symbolicznie wzmacniały zwyczajowe granice wspólnoty" (Cohen 2003: 196). 
Rodzimowierstwo a straight edge: budowanie aryjskiego ducha...

pijaństwie (np. Moskalewicz, Zieliński 1995) i „głodzie mięsa” (Harris 1985). Wszystko to prowokuje do przyjrzenia się bliżej znaczeniu używek i pożywienia w życiu rodzimowierców, a szczególnie Wilków.

W swojej analizie nie będę podążał tropem poszczególnych substancji, drugorzędne znaczenie ma także dla mnie rozróżnienie na życie obrzędowe i codzienne. Moją intencją jest analiza tych aspektów (punktów odniesienia) tożsamości, które członkowie ZZPW starają się kształtować, budować czy wręcz karmić: duchy i wspólnotę, ciało i wreszcie ducha. Starając się uchwycić specyfikę prawicowego sXe, ostatecznie chciałbym wykazać, że chociaż restrykcje w zakresie konsumpcji wydają się odnosić w ZZPW do sfery ciała, to w istocie są zorientowane na sferę ducha.

\section{Duchy i wspólnota}

Obrzędy religijne wszystkich grup neopogańskich powiązane są z kalendarzem rolniczym i dlatego kluczowym elementem rytuałów odprawianych przez neopogan słowiańskich są płody rolne rzucane w ogień przez kapłanów/kapłanki i/lub spożywane przez nich/nie jako bezkrwawa ofiara $^{6}$ dla (duchów) przodków/bogów/ziemi/przyrody. Różnica w podejściu do teologii pogańskiej, która w Polsce werbalizowana jest explicite kategoriami „panteizm” albo „politeizm”, przekładając się bezpośrednio na odpowiednio prawicową albo lewicową orientację polityczną, stanowi dość uniwersalny czynnik różnicujący formę i symboliczne znaczenie rytuałów, w ramach których bogowie/przodkowie są odpowiednio słabo folkloryzowanymi metaforami natury albo silnie folkloryzowanymi bytami nadnaturalnymi. Innymi czynnikami generującymi różnice w sposobach świętowania zmian pór roku przez neopogan słowiańskich są kraj (region), grupa, a także upływu czasu. Niemniej święta w cyklu rocznym posiadają swoiste znaki rozpoznawcze w postaci określonego pożywienia (chociaż może pojawiać się ono jedynie pod postacią metonimii czy nawet metafory), natomiast pieczywo i jakiś rodzaj napoju, często alkohol, stanowią wspólnie podstawę rytuałów. Na gruncie neopogaństwa słowiańskiego funkcję rytualnego pieczywa pełni powszechnie kołacz, zaś rytualnego napoju - miód pitny. Rytuały religijne ZZPW nie stanowią wyjątku od tej reguły.

${ }^{6}$ Niemniej choćby w Rosji składa się także (bezkrwawe) ofiary z mięsa (zabitego wcześniej zwierzęcia), a nawet zdarzają się krwawe ofiary (Shizhenskiy 2017: 168-172). 
Bezdyskusyjnie wybór tych substancji jako rytualnej podstawy pozostaje w związku z przekazami kronikarskimi dotyczącymi pogańskiej religii Słowian (Labuda 2003) oraz materiałami historyczno-etnograficznymi dotyczącymi życia polskich chłopów i szlachty (Kitowicz 1840, Bystroń 1933), które rodzimowiercy poddają daleko idącej homogenizacji, co doskonale ilustruje casus miodu pitnego. O ile uświęcenie spożywania alkoholu jest poświadczone historycznie i przez kronikarzy wiązane było właśnie ze Słowianami, o tyle wszystko wskazuje na to, że spożywanie konkretnie miodu pitnego w kontekście religijnym nie stanowi elementu słowiańskiej tradycji, lecz jest innowacją kulturową, sięgającą jako wyobrażenie romantyzmu ${ }^{7}$. Praktyka taka pojawiła się dopiero na początku lat 90. XX w., najprawdopodobniej pod wpływem neopogaństwa germańskiego (np. Sołtysiak 1999) - gdzie z kolei innowacją kulturową jest spożywanie alkoholu w kontekście stricte religijnym ${ }^{8}$ - chociaż może to być także niezależna wschodnioeuropejska innowacja (np. Tupešu 1987). Mimo że choćby w Rosji "Wiele wspólnot ma jasne reguły wyraźnie zakazujące napojów alkoholowych przez cały czas trwania spotkań [o charakterze] rytualnym" (Aitamurto 2016: 119, przyp. 13), a niektóre grupy bezpośrednio pod wpływem ideologii sXe w ogóle zaprzestają rytualnego

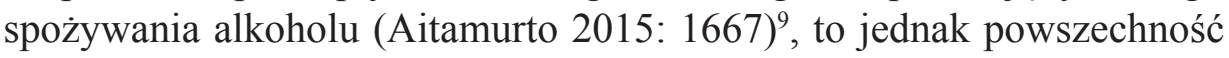
wykorzystania miodu pitnego przez neopogan słowiańskich w celach religijnych jest nie tylko świadectwem jego sakralizacji i poganizacji, ale także próbą slawizacji, a nawet - przynajmniej w Polsce - unarodowienia tego gatunku alkoholu. Przedkładaniu miodu pitnego nad bardziej popularne współcześnie rodzaje alkoholu (piwo, wódkę, wino itd.) wtóruje przedkładanie kołacza nad powszedni chleb. Afirmacja i sakralizacja tego, co archaiczne i ludowe, znajduje swoje dodatkowe podkreślenie

${ }^{7}$ Scott Simpson (2010: 123-124) słusznie zauważa, że w średniowiecznych kronikach brakuje wyraźnych informacji o spożywaniu miodu pitnego, mowa jest tylko o winie lub ogólnie o alkoholu. Najwyraźniej Słowianie w celach rytualnych używali wina, które jako towar elitarny zajmowało w ramach ekonomii symbolicznej pozycję dużo wyższą niż powszechnie dostępny wówczas miód czy piwo. Z kolei w późniejszym okresie podstawowym trunkiem spożywanym przez chłopstwo była wódka (Pobłocki 2014).

${ }^{8}$ Symbel ma charakter religijny, niemniej źródła historyczne (np. Tacyt) nie wskazują, aby spożywanie alkoholu przez starożytnych Germanów miało taki właśnie charakter.

${ }^{9}$ Rosja nie stanowi oczywiście odosobnionego przypadku. Jedna z ukraińskich grup używa w celach rytualnych wody i mleka (np. Lesiv 2013: 26-27). Poza neopogaństwem słowiańskim rytualne spożywanie alkoholu bywa kontestowane choćby na Litwie (Petrusevičiūtè 2010: 83). 
Rodzimowierstwo a straight edge: budowanie aryjskiego ducha...

w świadomym wprowadzeniu przez neopogan słowiańskich do swoich obrzędów tradycyjnych materiałów rzemieślniczych, takich jak glina, drzewo, len, żelazo i róg (z którego wykonuje się rogi do picia miodu).

Sposób spożywania miodu pitnego i kołacza ma ogromne znaczenie dla budowania wspólnoty (tożsamości) na poziomie mikrospołecznym. Scenariusz typowego rytuału ZZPW przewiduje, że po złożeniu ofiary do wszystkich uczestników ustawionych w kręgu po kolei podchodzą kapłanki trzymające wielki kołacz oraz róg wypełniony miodem (ewentualnie dodatkowe produkty, np. jaja). Każdy z uczestników odłamuje sobie kawałek kołacza i, otrzymując do rąk róg, wznosi toast i/lub okrzyk „sława!”, po czym upija miodu (w tym czasie zebrani odpowiadają chórem ,sława!”) i dopiero oddawszy róg kapłance, by mogła uzupełnić jego zawartość, przystępuje do spożycia kołacza (i ewentualnie dodatkowego produktu). W przebiegu rytuału nie pozostaje bez znaczenia podział ról płciowych, ${ }^{10}$ zgadzam się jednak ze Scottem Simpsonem (2008a, 2008b), że w zrytualizowanym piciu miodu pitnego w kręgu najistotniejsza jest implicytna zasada współ-substancjalności, wyrażająca się dzieleniem naczynia i chóralną odpowiedzią: ,sława!’. Dopełnienie jego analizy o rytualną praktykę dzielenia się kołaczem lub spożywania jaj (a więc jedzenia tej samej substancji) pozwala mi uwypuklić wspomnianą zasadę współ-substancjalności w biesiadowaniu. Niewątpliwie jedzenie z jednego naczynia i chóralne wykrzykiwanie ma moc tworzenia wspólnoty na poziomie wyobrażeń ${ }^{11}$, ale odciska także swoje piętno na poziomie realności. Kluczowe znaczenie w procesie upodabniania się i identyfikowania się ze sobą ma jednak nie tyle akt dzielenia się tym samym naczyniem, co raczej akt spożywania tego samego pokarmu (Carsten 1995, Rival 1998), czego w jakiś sposób Simpson jest świadomy, wzmiankując o ,bakteriach” (Simpson 2008a: 221) ${ }^{12}$. Mówiąc o upodabnianiu się, nie mam oczywiście

${ }^{10}$ Prowadzenie rytuałów i upijanie miodu podczas składania ofiary leży zawsze w gestii mężczyzn, a kapłanki zajmują się jedynie dystrybucją żywności (wyjątkiem są tylko Szczodre Gody i zapewne Luperkalia, w których nie dozwala się uczestniczyć kobietom), dodatkowo uczestniczki rytuału (niemal) zawsze ograniczają swój toast do zawołania ,sława!"

${ }^{11} \mathrm{~W}$ tym kontekście warto zwrócić uwagę na dary wnoszone przez gości biorących udział w obrzędach ZZPW, które odwzajemniane były rytualnym kołaczem i miodem pitnym, i na kwestię gościnności w ogóle.

12 Odmowa rytualnego dzielenia się naczyniem i spożywanie tego samego jedzenia wytwarza różnicę. Rzeczywiście, sprzeciw wobec picia z jednego rogu, motywowany względami higienicznymi, doprowadził do rozłamu w Zachodniosłowiańskim Związku Wyznaniowym Słowiańska Wiara i w konsekwencji do utworzenia grupy Watra. 
na myśli podobieństwa twarzy, lecz będące efektem określonej diety podobieństwo ciał czy afektów: sylwetek, zapachu, a nawet schorzeń. Oczywiście rytualne spożywanie miodu pitnego i kołacza nie prowadzi do widzialnej transformacji cielesności rodzimowierców, ale nie powinno się lekceważyć wpływu nawet niewielkiej ilości spożytego miodu pitnego na ich ciała (zapach alkoholu wydzielany z ust, szybsze tętno, ciepło w przełyku) i umysły czy kwestii kuchni narodowej. I oczywiście nie sposób przecenić symboliczne znaczenie spożywania tej samej substancji (z tego samego naczynia).

Nadszedł czas, by przyjrzeć się innym rodzajom pożywienia występującym w dorocznych rytuałach ZZPW. W przypadku Jarych Godów (ok. 21 marca) kluczowym symbolem jest jajo, aczkolwiek obrzęd w 2004 r. toczył się pomimo braku jaj - czego byłem wówczas nieświadomy - bowiem osoba odpowiedzialna za ich dostarczenie nie wypełniła swojego zadania; rolę substytutu odegrały orzechy i zioła. W przypadku Święta Plonów (ok. 23 września) kluczową rolę odgrywa ziarno zbóż, jednak osobiście nigdy nie miałem okazji zaobserwować rytuałów z tym świętem związanych. W czasie Szczodrych Godów (ok. 24 grudnia) nie dostrzegłem obecności żadnego kluczowego symbolu, z wyjątkiem właśnie miodu pitnego i kołacza ${ }^{13}$.

W przypadku pozostałych świąt kluczowe symbole mają związek z pożywieniem jedynie pośrednio. W czasie Nocy Kupały (ok. 22 czerwca) najważniejszym elementem wydaje się wianek pleciony z różnorakich gatunków kwiatów, ale także ziół czy kłosów zbóż, które ze względu na wartości odżywcze bądź właściwości lecznicze odgrywały (i nadal odgrywają) istotną rolę w diecie społeczności rolniczych. W czasie Dziadów (1 listopada) kluczowym symbolem jest znicz, pierwotnie wyrabiany z wosku pszczelego, który związany jest z pożywieniem poprzez bezpośrednią styczność z miodem, a więc substancją o fundamentalnym znaczeniu dla rytuałów neopogan słowiańskich. Niestety, rodzimowiercom zdarza się zakup zniczy wyrabianych z parafiny, więc ich związek z miodem jest już tylko i wyłącznie metaforyczny.

Wilki obchodzą dwa dodatkowe święta, które nie mają jawnie religijnego charakteru i są oderwane od kalendarza rolniczego. Podczas

${ }^{13}$ Dla celów porównawczych odnotuję, że zaprzyjaźniony z ZZPW Zakon Krwi Aryjskiej, a właściwie jego damska sekcja "Bogini Wojny", dwukrotnie zorganizował ku czci domniemanej bogini życia w dniu 1 maja Święto Żywii, którego kluczowym symbolem było jabłko. 
Rodzimowierstwo a straight edge: budowanie aryjskiego ducha...

Luperkaliów (ok. 15 lutego) inicjuje się nowych członków grupy, dokonując m.in. skaryfikacji, a więc w istocie składając ofiarę $\mathrm{z}$ ich krwi, co stanowi rzadko spotykaną praktykę w obrębie rodzimowierstwa (cf. Simpson 2000, 152) i neopogaństwa słowiańskiego (Shizhenskiy 2017, 172). Z kolei 11 listopada grupa aktywnie włącza się w obchody Święta Niepodległości, składając wieniec pod pomnikiem Józefa Piłsudskiego.

W odróżnieniu od ruchów neopogańskich działających w Europie Zachodniej czy Ameryce Północnej, Wilki wydają się nie przywiązywać szczególnej uwagi do kwestii ekologii, i to pomimo pewnego okresu współpracy z polskimi środowiskami ekologicznymi. Chociaż Wilki, przygotowując każdorazowo pochodnie na cele obrzędu, wykorzystują wtórnie surowce, takie jak stare ubrania czy zużyty olej silnikowy, to mam wątpliwości, czy stanowi to wyraz recyklingu i, szerzej, ochrony środowiska, jako że obserwowałem akty wrzucania w ogień (po zakończeniu rytuału) plastiku czy aluminiowych puszek, a nawet kanistra z resztkami benzyny. Na zdecydowane uznanie zasługuje jednak sprzątanie miejsca rytualnego następnego dnia po przeprowadzeniu rytuału, którego dokonują wyznaczeni do tego zadania członkowie ZZPW.

\section{Ciało}

Nadszedł czas, by przyjrzeć się codziennym strategiom żywienia. Powstrzymywanie się od jedzenia produktów pochodzenia zwierzęcego, lub przynajmniej mięsa, jest tendencją zdecydowanie narastającą w obrębie subkultury straight edge, nie należy jednak do „wartości rdzennych” (Haenfler 2006: 32-57). Jeśli natomiast chodzi o neopogaństwo, czy raczej jego prototyp w postaci wicca (ale także druidyzm i neoszamanizm), to zdaniem badaczy weg(etari)anizm od dawna jest jego specyfiką. Ten rodzaj dietetycznych ograniczeń skłania nie tyle do pytania o związki interetnicznych nurtów neopogaństwa z aktualną na Zachodzie modą na bycie „Wege" (Maurer 2002) oraz z ruchem New Age (i religiami Wschodu), ale przede wszystkim do konfrontacji tego obrazu ze strategiami odżywiania się rodzimowierców.

O ile mi wiadomo, mięso $\mathrm{i}$ inne produkty pochodzenia zwierzęcego stanowią codzienny składnik ich diety, co wydaje się wynikać ze specyfiki polskiej kuchni narodowej (Dembińska 1963, Kleśta-Nawrocka 2016), która w dużej mierze opiera się właśnie na mięsie, przede wszystkim 
drobiu hodowlanym, wieprzowinie i dziczyźnie ${ }^{14}$. Na charakterze kuchni polskiej na pewno odcisnął swoje piętno chłodny klimat, który, mówiąc krótko, nie sprzyja praktykowaniu diety weg(etari)ańskiej, ciążąc ku bogatej w tłuszcze (wysokokalorycznej) diecie mięsnej. Jednakże szczególnie podkreślić trzeba czynniki o wymiarze społecznym, takie jak ,pragnienie oralne" (Gow 1989) smaku mięsa, którego nie sposób ograniczać do „głodu mięsa” epoki komunizmu (Harris 1985), i związek między jedzeniem mięsa a wysokim statusem ekonomiczno-politycznym. Dlatego też konsumpcja mięsa przez rodzimowierców stanowi wyraz narodowych preferencji żywieniowych, które odróżniały Polaków od innych narodów, mających odmienne nawyki żywieniowe (kartoflarzy, makaroniarzy, żabojadów itd.).

$\mathrm{Na}$ osobną uwagę zasługują ograniczenia narzucone przez Kościół Rzymskokatolicki na spożywanie mięsa i pokarmów mięsnych, a nawet na same posiłki. Siłę tych ograniczeń najłatwiej dostrzec poprzez definicję mięsa, które w Polsce zwyczajowo nie obejmuje ryb i innych zwierząt zmiennocieplnych (raków, ostryg, żółwi), a także zwierząt stałocieplnych prowadzących „mokry” tryb życia: bobrów, wydr i ptactwa wodnego (zob. Kitowicz 1840: 144). Rodzimowiercy kontestują nie tyle zasadę obowiązującego okazjonalnie postu ścisłego, co raczej zasadę wstrzemięźliwości od pokarmów mięsnych właściwie we wszystkie piątki całego roku. Jedzenie mięsa bez żadnych kalendarzowych ograniczeń stanowi dla nich bardzo widoczny znak przeciwstawienia się zniewalającym zasadom chrześcijaństwa jako religii obcej, gdyż, podkreślam, nie chodzi o odrzucenie idei samego ujarzmiania, ale tylko i wyłącznie ujarzmiania na obcych zasadach ${ }^{15}$.

Preferowanie zwyczajowych dla kuchni polskiej produktów żywnościowych skłania rodzimowierców do częstszego wybierania żywności wyprodukowanej w Polsce i, okazjonalnie (z uwagi na wysokie ceny), produktów tradycyjnych, niemniej nawet w przypadku ZZPW nie wyklucza to spożywania produktów importowanych: obcych etnicznie/rasowo bądź ideologicznie. Pomijając produkty, których egzotyczność jest

${ }^{14}$ Mówiąc o polskiej kuchni narodowej nie powinniśmy zapominać o specyfice dziennego rytmu spożywania posiłków, ale tej kwestii również nie mogę poświecić $\mathrm{z}$ braku miejsca należytej uwagi.

${ }^{15} \mathrm{~W}$ świetle powyższego jest pewnym zaskoczeniem, że rodzimowiercy nie składają ofiar z krwi lub choćby mięsa, bo wydaje się to być konsekwencją zniesienia przez chrześcijaństwo ofiary ze zwierząt wobec jednokrotnej krwawej samoofiary Chrystusa. 
Rodzimowierstwo a straight edge: budowanie aryjskiego ducha...

właściwie niedostrzegana (ryż czy kawa i herbata), Wilki konsumują zarówno żywność wyraźnie egzotyczną, choćby „chińszczyznę”, jak i produkty upowszechnione na rynku polskim wraz z upadkiem komunizmu, takie jak cytrusy, pizza czy... Coca Cola, bojkotowana przecież w toku swojej historii wielokrotnie i przez różne siły (Pendergrast 2000), czego wyrazem na gruncie neopogaństwa słowiańskiego jest popularność kwasu chlebowego. Niemniej, w odróżnieniu od wielu rodzimowierców, Wilki nie wytwarzają kwasu chlebowego i nie pozyskują oskoły, które w środowisku noszą status napojów „pogańskich"16, co więcej, nie dostrzegłem świadectw ich codziennej konsumpcji. W ich przypadku wyrazem patriotyzmu ekonomicznego był przede wszystkim sprzeciw wobec wstąpienia Polski do Unii Europejskiej, które miało się wiązać (nie tylko ich zdaniem) z upadkiem polskiego rolnictwa i utratą ziemi, i sprzeciw wobec konsumpcjonizmu i kultury popularnej.

Omówiwszy kulinarny aspekt nacjonalizmu ZZPW, mogę skoncentrować się na polityce seksualnej mięsa (Adams 2010). W kulturze Zachodu mięso ulega maskulinizacji poprzez jego symboliczne nacechowanie siłą czy władzą, które z kolei są wiązane z rolą płciową mężczyzny, i nie inaczej rzecz się przedstawia w przypadku ZZPW. Nawet jeśli zwierzęta są w dyskursie słownym członków grupy nieobecnym przedmiotem odniesienia, to jednak dla Wilków jedzenie mięsa stanowi wyraźną implikację drapieżności i uśmiercania zwierząt (nawet jeśli to nie oni dokonują aktu ich zabicia), co pozostaje w bezpośrednim związku z wojowniczością i agresją, stanowiącymi podstawowe wartości etyki aryjskiej, która przenika „Polski Narodowy Socjalizm” wyznawany przez ZZPW.

Upłciowienie mięsa przez androcentryczną i patriarchalną ideologię grupy przejawia się nie tylko na poziomie symbolicznym, ale i na poziomie materialnym, jako że mięso jest jedną z podstawowych substancji budujących tężyznę fizyczną mężczyzny-wojownika. Doktryna ZZPW jednoznacznie wynosi ducha ponad ciało, jednocześnie jednak zachowuje wyraźną rezerwę wobec intelektualizmu czy artyzmu, gloryfikując pracę fizyczną i materialne oddziaływanie na świat, poprzez które manifestuje się „wola mocy” czy witalność ducha, czyniąc ideałem człowieka aryjskiego herosa, wojownika, żołnierza-robotnika. Nie jest zatem niczym zaskakującym, że pomimo drugorzędności ciała czy materii w ideologii

${ }^{16}$ Wspomniane produkty, a także miód pitny i kołacz, wydają się odciskać swoje piętno na etnocentryzmie polskich konsumentów (Good, Hiddleston 1995). 
ZZPW kwestia sprawności fizycznej stanowi w życiu codziennym grupy jeden $\mathrm{z}$ ważniejszych tematów, a odpowiednia dieta oraz ćwiczenia fizyczne stanowią podstawę sukcesu w tym zakresie.

Apoteoza siły fizycznej skłania nie tyle do stosowania zbilansowanej diety i regularnego uprawiania sportu dla trwałego utrzymania, względnie nieśpiesznego podnoszenia ogólnej sprawności fizycznej, ale raczej do widocznego (szybkiego) przyrostu masy mięśniowej. $Z$ tego powodu niektórzy członkowie grupy trenujący na siłowni, zwłaszcza ci najmłodsi, decydują się na restrykcyjne stosowanie diety wysokobiałkowej - czyli spożywanie produktów bogatych w proteiny, takich jak (nie licząc mięsa i ryb) ryż, nabiał czy banany - a także na stosowanie sterydów anabolicznych, które stymulują wzrost masy mięśni, siły i wytrzymałości, a nawet na wstrzemięźliwość seksualną, aby, zgodnie z obiegową opinią, zapobiec utracie testosteronu.

Pod wieloma względami słuszne jest zatem twierdzenie, że w kontekście ćwiczeń siłowych "Uwaga skupia się na jedzeniu, które pojmuje się raczej jako budulec lepiej wyglądającego, dłużej żyjącego ciała, niż jako źródło przyjemnych doświadczeń czy oznacznik tożsamości kulturowej” (Parasecoli 2005: 26). Muszę jednak podkreślić, że dla Wilków rzeczą o pierwszorzędnym znaczeniu nie jest ani uroda, ani zdrowie, lecz siła. Pojmują oni ciało przede wszystkim jako narzędzie pracy i walki, co zmusza do myślenia o muskulaturze w kategoriach pragmatycznych („tu i teraz”), zamiast w kategoriach estetycznych (Featherstone 2008) czy medycznych (Turner 1982), chociaż oczywiście członkowie ZZPW doceniają estetyczne walory atletycznej budowy ciała i pamiętają, że wytrenowane ciało stanowi także doskonałą inwestycję na przyszłość (starość). Nawet jeśli sposób pojmowania ciała przez ZZPW nie jest wyjątkowy, gdyż w niektórych grupach możemy odnaleźć podobne koncepcje, to bezsprzecznie podważa on globalną kulturę konsumpcyjną na sposób lokalny.

Kupowanie, gromadzenie i gotowanie pożywienia to rodzaj aktywności, które na Zachodzie łączone są z domeną kobiecości. W kontekście rytuałów, jak już wspomniałem, niemal wyłącznie kobiety zajmują się dystrybucją żywności, wypełniając przypisaną im rolę płciową karmicielki. Również w domach Wilków zadanie przygotowania żywności spoczywa generalnie na partnerkach lub matkach, i tylko w przypadku prowadzenia niezależnych gospodarstw domowych przygotowanie posiłku z oczywistych względów spoczywa na barkach mężczyzny. Wyjątkiem od tej reguły 
Rodzimowierstwo a straight edge: budowanie aryjskiego ducha...

jest z całą pewnością kulinarne zaopatrzenie rytuałów. Zakup miodu pitnego, upieczenie kołacza czy ugotowanie jaj i przetransportowanie ich na miejsce obrzędu, jako działania przydzielone mężczyznom przez innych mężczyzn i dodatkowo uświęcone poprzez uwikłanie w rytuał religijny, nie są postrzegane jako działania kobiece, lecz wręcz przeciwnie - jako zadania wybitnie męskie, za których niewypełnienie grozi surowa i męska kara.

\section{Duch}

Statut ZZPW, zredagowany w momencie założenia grupy w 1997 roku, określa jako jeden ze swoich celów „Przestrzeganie zdrowego trybu życia (niezażywanie narkotyków, nienadużywanie alkoholu)" ${ }^{17}$. Byłoby błędem pojmowanie tego jakże sXe'owego nakazu jedynie w kategoriach biomedycznych, gdyż członkowie ZZPW nie kultywują przecież jedynie siły ciała, ale co najmniej w takim samym stopniu - jak już wspomniałem - oddają cześć sile umysłu i duszy. Pojęcie „zdrowia” jest tutaj głęboko lokalne, uwikłane w ideologiczną relację między kulturą aryjską (ufundowaną na etyce aryjskiej) i wspakulturą żydowską, która stanowić ma jej zaprzeczenie, wiążąc nierozerwalnie te dwie sfery, co w dyskursie ZZPW wyrażają bezpośrednie przywołania starożytnej idei kalokagathii, oznaczającej połączenie piękna z dobrem, czyli inaczej mówiąc - estetyki (ciała) z etyką (ducha). Wstrzemięźliwość względem używek dotyczy oczywiście samych substancji, dotykając sfer fizyczności i psychiki, przede wszystkim jednak ograniczenia wymierzone są w sposób obchodzenia się $\mathrm{z}$ nimi, a zatem w sferę ducha.

W odróżnieniu od hardcore'owego sXe, dla ZZPW alkohol nie jest przedmiotem całkowitej abstynencji, ale jego spożywanie powinno być kontrolowanie przez pijącego, nad którym jednocześnie kontrolę sprawuje cała grupa. Pijaństwo dowodzi słabej woli, godząc w normy etyczne grupy. Analizę rytualnej konsumpcji alkoholu warto dopełnić o analizę tego czasu, który następuje tuż po zakończeniu samego obrzędu. O ile rytualne spożywanie tego samego alkoholu (zazwyczaj miodu pitnego) jako uświęconej substancji jednoczy wszystkich uczestników obrzędu ze sobą nawzajem i z przodkami/bogami/naturą na poziomie symbolicznym, o tyle po zakończeniu obrzędu spożywa się jakiś alkohol (zwykle piwo

${ }^{17}$ Dokument wewnętrzny organizacji, w posiadaniu autora. 
lub wino, ewentualnie pozostały miód) w celach czysto towarzyskich; zwykle najpierw w małych grupkach na miejscu rytuału w lesie i później, po powrocie do miasta, wspólnie przy jednym stole, jeśli to tylko możliwe. Chyba tylko obchody Kupały stwarzają możliwość długiego, a nawet całonocnego biesiadowania w lesie.

Alkohol jako narzędzie socjalizacji wspomaga wymianę informacji (która rozpoczyna się przed obrzędem) i zacieśnianie międzyjednostkowych więzi. Takie porytualne spożywanie alkoholu stanowi zwyczajowy element spotkań z okazji świąt neopogańskich nawet wówczas, gdy w ramach rytuału alkohol spożywają tylko ofiarnicy (np. Kupała Rodzimego Kościoła Polskiego w 2005), a być może nawet i wtedy, gdy alkohol nie stanowi elementu samego rytuału. W miejscu obrzędowym dozwala się spożywać alkohol jedynie w niewielkich ilościach i rzeczywiście w przypadku Wilków nigdy nie widziałem odstępstwa od tej reguły. Zasadniczo dopiero poza uświęconym gruntem (względnie w późniejszym czasie) dozwolone jest bardziej nieskrępowane spożywanie alkoholu, nigdy jednak nie powinno prowadzić do upicia się. Nigdy nie widziałem Wilków łamiących i tę regułę, chociaż różne doniesienia dotyczące środowiska neopogan etnicznych wydają się dowodzić, że zasada powściągliwości w porytualnym spożywaniu alkoholu bywa jednak łamana. Nigdy nie zauważyłem spożywania alkoholu przez członków ZZPW przed rytuałem i ten rodzaj wstrzemięźliwości wydaje się być szerzej praktykowany w środowisku rodzimowierczym.

Poza kontekstem rytualnym warto zwrócić uwagę na spożywanie alkoholu w czasie spotkań towarzyskich. Moje spotkania z pojedynczymi członkami ZZPW odbywały się bez udziału alkoholu, aczkolwiek przy okazji mniej oficjalnych spotkań zdarzało nam się wspólnie spożyć niewielką ilość piwa. Nigdy nie brałem udziału w spotkaniach organizowanych przez członków grupy w celach rozrywkowych, takich jak urodziny czy sylwester, niemniej informacje pozyskane drogą wywiadu wskazują, że alkohol był podczas nich spożywany, i to w większych ilościach. Dla kontrastu, niektórzy z aspirujących do wstąpienia w szeregi ZZPW, którzy przez wiele miesięcy regularnie ćwiczyli na siłowni, kształtując swoje ciała, nie tylko stosowali dietę wysokobiałkową, ale na ten czas zupełnie odrzucali alkohol. Pewne poszlaki wskazują, że tylko członek grupy ze specyficzną biografią, będący „dzieckiem ulicy”, spożywał alkohol z mniejszą powściągliwością, jednak, co podkreślam, nigdy nie naruszył on w żaden sposób powagi rytuałów czy innych oficjalnych spotkań, co 
Rodzimowierstwo a straight edge: budowanie aryjskiego ducha...

w moim przekonaniu stanowi zarówno ilościową, jak i jakościową miarę skuteczności ZZPW w zwalczaniu alkoholizmu.

Jak wspominałem, przyjmowanie sterydów nie jest w ZZPW zabronione i dlatego niektórzy z Wilków stosują je jako wspomagacze ćwiczeń siłowych. Niemniej jednak nadużywanie sterydów niesie ze sobą niebezpieczeństwo nie tylko skutków ubocznych, które czasowo mogą prowadzić do poważnego pogorszenia stanu zdrowia, ale także zostania wydalonym z grupy, co miało miejsce w (przynajmniej) jednym przypadku.

O ile w przypadku alkoholu czy sterydów zakazuje się ich nadużywania, o tyle zażywanie narkotyków jest jednoznacznie zabronione. Moje obserwacje nie wykazały ani jednego przypadku naruszania tego zakazu, aczkolwiek jeden z byłych członków bractwa wojów Wataha „Wilcze Kły" z Poznania, które na przełomie tysiącleci współpracowało z Wilkami, palący regularnie marihuanę, opowiedział mi pewnego razu w formie plotki, jakoby palił kiedyś jointa z jednym z liderów ZZPW. Nawet jeśli sytuacja taka miała rzeczywiście miejsce, a co więcej - nawet jeśli nie był to przypadek odosobniony, to pozyskane dane etnograficzne dowodzą nie tyle podporządkowania się zakazowi z obowiązku, co raczej jego afirmacji z własnej, nieprzymuszonej woli. Doskonałego dowodu dostarcza jeden z najaktywniejszych Wilków, dla którego jednym z motywów wstąpienia w szeregi grupy była właśnie walka $\mathrm{z}$ nałogiem. Jego sukces wystawia ZZPW wspaniałe świadectwo.

Chociaż w Statucie ZZPW brak zakazu spożywania tytoniu, papierosy palą tylko pojedynczy członkowie grupy. Właściwie tylko mężczyzna mniej powściągliwie spożywający alkohol palił nałogowo. Warto jednak podkreślić symboliczny wymiar ograniczeń, które sam sobie narzucił, nie paląc nigdy w granicach kamiennego kręgu stanowiącego miejsce obrzędowe, by „nie kiepować zmarłym na głowy”. Jego działania dobitnie ukazują, że ograniczenie palenia - i wszystkie inne ograniczenia - służą nie tyle posiadaniu zdrowego ciała, co zdrowego ducha.

Doskonałym potwierdzeniem tej tezy jest pewna mutacja reguły sXe, nakazującej powstrzymywanie się od stosunków seksualnych z przypadkowymi partnerami, która w Kodeksie Postępowania ZZPW ma formę nakazu przestrzegania zasad eugeniki, czyli innymi słowy dbania o to, by partnerka była „,czystej krwi”, czyli rasy białej (dopuszczalna jest narodowość inna niż polska), i nie reprezentowała niższej wartości genetycznej. Chociaż zasady ZZPW nie mają charakteru ilościowego, pewnym ogranicznikiem ilości partnerów jest z całą pewnością wysoka wartość przypi- 
sywana rodzinie, a tym samym monogamicznemu związkowi. Zrozumiałe jest podjęcie tematu życia seksualnego w kontekście ruchu sXe (seks czy kobiety jako rodzaj używki lub nawet uzależnienia), niemniej w ramach analizy strategii konsumpcyjnych może wydawać się nie na miejscu. Z tego powodu pozwolę sobie zwrócić uwagę, że stosunek seksualny wiąże się generalnie z połykaniem śliny (i potu), nierzadko także wydzieliny pochwy i/lub spermy, które, nawet jeśli formalnie nie są uznawane za środki spożywcze czy używki, stanowią wedle wielu społeczeństw formę pożywienia (np. Herdt 1984, Gow 1989). Nie sposób też zignorować powszechne (nie tylko) w kulturze Zachodu symboliczne zrównanie kobiety z pożywieniem czy metaforę seksu jako pożywienia/jedzenia, którą w pierwszym rzędzie wyraża pojęcie penetracji jako konsumpcji.

\section{Podsumowanie}

Samodyscyplina względem używek stanowi jeden z kluczowych motywów kształtowania tożsamości członków ZZPW. Jednocześnie jednak styl życia praktykowany przez ZZPW jest zdecydowanie mniej radykalny od oryginalnego $\mathrm{sXe}$, ponadto uwidaczniają się w nim wpływy tożsamości narodowej i religijnej. Radykalne zerwanie dotyczy tylko narkotyków, natomiast alkohol jest programowo spożywany w ramach rytuałów religijnych, a także poza nimi. Zakazana nie jest sama substancja, lecz jedynie praktyka nadużywania alkoholu. Dozwolone jest nawet spożywania alkoholu w większej ilości przy okazji urodzin czy sylwestra, o ile nie prowadzi to do naruszeni własnej godności. Brak sprzeciwu wobec spożywania alkoholu stanowi wyraz zarówno naturalizacji obecności alkoholu w społeczeństwie, jak i dojrzałości w sposobie obchodzenia się $\mathrm{z}$ alkoholem, stanowiąc zaprzeczenie radykalizmu postawy młodzieżowej. Rzecz przedstawia się podobnie w przypadku brania sterydów, a nawet jedzenia mięsa, bo jeśli mięsożerność jest atrybutem mężczyzny, to otyłość (jako nadużywanie mięsa) stanowiłyby w oczach ZZPW przedmiot krytyki.

Ograniczenia seksualne mają wymiar przede wszystkim rasowy i eugeniczny, który jest nieobecny w lewicowym sXe. Chociaż nie dotyczą one bezpośrednio ilości partnerów czy głębokości relacji, to poprzez wartości narodowe i prorodzinne w ostatecznym rozrachunku prowadzą w tym samym kierunku - tworzenia trwałych relacji. Przypadkowy seks nie stanowi zaprzeczenia wartości sXe, a raczej poprzez swoją rzadkość 
Rodzimowierstwo a straight edge: budowanie aryjskiego ducha...

potwierdza je (i dodatkowo męskość). Kluczem do zrozumienia istoty sXe w wykonaniu ZZPW jest ponownie nienadużywanie.

Obojętność ZZPW względem tytoniu, oraz przyzwolenie na przyjmowanie alkoholu i sterydów czy na przypadkowy seks (a także jedzenie mięsa), co niejako zmiękcza oryginalne zakazy sXe, w sposób jasny dowodzi, że wszystkie ograniczenia ZZPW nie są zorientowane na zdrowe odżywianie ciała, lecz na odżywianie zdrowego - samodyscyplinującego się, a nie ujarzmionego wbrew woli czy zmuszonego do posłuszeństwa - aryjskiego ducha. Dla ZZPW wszystkie te narzucone sobie ograniczenia nie stanowią celu samego w sobie, a jedynie są środkiem do celu, jakim jest dążenie do nadczłowieczeństwa i przezwyciężanie słabości.

Przede wszystkim jednak ograniczenia tego rodzaju służą celom społecznej interakcji. To, że „Subkulturę [sXe] tworzą głównie biali mężczyźni i kobiety w wieku 13-25 lat z umiarkowanie religijnych rodzin klasy średniej" (Williams, Copes 2005: 69-70) na pewno sprzyja przejmowaniu tego rodzaju stylu życia przez ruch białej supremacji, ale bynajmniej nie tłumaczy, dlaczego idee sXe stały się tak ważnym elementem tożsamości dla niektórych z aktywistów tego ruchu. Kluczem wydaje się geneza ruchu sXe, który pierwotnie stanowił jedną z hardcore'owych form reakcji wobec nadmiernego spożywania alkoholu, palenia papierosów i zażywania narkotyków w ramach subkultury punk. Na gruncie ruchów ekstremalnie prawicowych postawa sXe analogicznie służy zbudowaniu dystansu względem głównego nurtu ruchu skinhead. W istocie dezaprobata neopogańskiego ZZPW wobec (potencjalnego) rozpasania Innych, skrajnie prawicowych rodzimowierców stanowi potwierdzenie tezy, że granice ustanawiane są $\mathrm{w}$ pierwszym rzędzie wobec grup najbliższych (Barth 2004), jako że rodzimowiercy generalnie nie nadużywają alkoholu i nie zażywają narkotyków.

Ze względu na młodzieżowy charakter dyskutowanych subkultur istnieje niebezpieczeństwo pewnej infantylizacji stylu życia ZZPW. Nawet jeśli Wilki rekrutowały się początkowo z szeregów młodzieży i oddziaływanie na młodzież stanowiło jeden z jawnie wyrażanych celów ZZPW, to zdecydowanie tożsamość grupy nie była nigdy budowana w opozycji do kultury „dorosłych” (ani innych subkultur młodzieżowych), ale w opozycji do całości społeczeństwa polskiego, naznaczonego alkoholizmem i katolicyzmem. Wilki sprzeciwiają się klasyfikowaniu ich działalności jako subkultury (Czerwiński 2000), pojmując ją w kategoriach kultury 
alternatywnej czy ruchu rewitalizacyjnego, aczkolwiek ich członkowie nie byli zdolni do werbalizacji swojego stanowiska w terminach socjologicznych czy antropologicznych. Mój punkt widzenia potwierdzają zmiany w strukturze demograficznej ZZPW: pomijając fakt, że szeregi grupy są obecnie niezwykle uszczuplone, jej członkami są obecnie mężczyźni w wieku ok. 40 lat, żyjący w stałych związkach (małżeńskich) i mający dzieci. Podobnych przypadków z innych grup jest bez liku.

\section{BILIOGRAFIA}

Aitamurto, K., Gaidukov A. (2013). Russian Rodnoverie: Six Portraits of a Movement. W: K. Aitamurto, S. Simpson (red.), Modern Pagan and Native Faith Movements in Central and Eastern Europe, s. 146-163. Durham: Acumen.

Aitamurto, K. (2015). Russian Rodnoverie: Revisiting Eastern and Western Paganisms. W: S.D. Brunn (red.), The Changing World Religion Map, s. 16551671. Durham: Springer.

Aitamurto, K. (2016). Paganism, Traditionalism, Nationalism. Narratives of Russian Rodnoverie. London and New York: Routledge.

Barth, F. (1966). Models of Social Organization. London: Royal Anthropological Institute.

Barth, F. (2004). Grupy i granice etniczne: społeczna organizacja różnic kulturowych. W: M. Kempny, E. Nowicka (red.), Badanie kultury. Elementy teorii antropologicznej. Kontynuacje (s. 348-377). Warszawa: Wydawnictwo Naukowe PWN.

Brown, T.S. (2004). Subcultures, Pop Music and Politics: Skinheads and "Nazi Rock" in England and Germany. Journal of Social History, 38 (1), 157-178.

Bystroń, J.S. (1933). Dzieje obyczajów w dawnej Polsce: wiek XVI-XVIII. Warszawa: Trzaska, Evert i Michalski.

Carsten, J. (1995). The Substance of Kinship and the Heat of the Hearth: Feeding, Personhood, and Relatedness among Malays in Pulau Langkawi. American Ethnologist, 22 (2): 223-241.

Cohen, A.P. (2003). Wspólnoty znaczeń. W: M. Kempny, E. Nowicka (red.), Badanie kultury. Elementy teorii antropologicznej (ss. 192-217). Warszawa: Wydawnictwo Naukowe PWN.

Czerwiński (2000, 19-20 sierpnia). Sezonowy zbuntowany. Glos Koszaliński/ Glos Stupski, 7. 
Rodzimowierstwo a straight edge: budowanie aryjskiego ducha...

Ćwik, G. (2017, 29 marca). Nacjonalistyczny Straight Edge: przeciwko temu co niewoli Naród. Szturm. Miesięcznik narodowo-radykalny, 30 (3), 12-16. http://szturm.com.pl/index.php/miesiecznik/item/513-grzegorz-cwik-nacjonalistyczny-straight-edge-przeciwko-temu-co-niewoli-narod.

Dembińska M. (1963). Konsumpcja żywnościowa w Polsce średniowiecznej. Wrocław, Warszawa, Kraków: Zakład Narodowy im. Ossolińskich, Wydawnictwo Polskiej Akademii Nauk.

Featherstone, M. (2008). Ciało w kulturze konsumpcyjnej. W: M. Szpakowska (red.), Antropologia ciała. Zagadnienia i wybór tekstów (s. 109-117). Warszawa: Wydawnictwo Uniwersytetu Warszawskiego.

Filip, M. (2008). O etnografię rodzimowierstwa: Wprowadzenie do etnografii Zakonu Zadrugi „Północny Wilk”. Państwo i Społeczeństwo, 8 (4): 107-121.

Filip, M. (2009). Neopogański nacjonalizm jako praktyka: Tożsamość Zakonu Zadrugi „Północny Wilk”. Państwo i Społeczeństwo, 9 (4): 45-57.

Filip, M. (2011). Polityka tożsamości we wspólnotach neopogańskich: Przykład Zakonu Zadrugi „Północny Wilk”. W: W. Dohnal, A. Posern-Zieliński (red.), Antropologia i polityka: Szkice z badań nad kulturowymi wymiarami wtadzy (s. 175-188). Warszawa: Instytut Archeologii i Etnologii PAN.

Filip, M. (2014). Rodzima Wiara (nie) tylko dla mężczyzn. O upłciowieniu prawicowego neopogaństwa słowiańskiego w Polsce. Zeszyty Etnologii Wroctawskiej, 20 (1): 113-133.

Fine G.A., Kleinman S. (1979). Rethinking Subculture: An Interactionist Analysis. American Journal of Sociology 85:1-20.

Foucault, M. (1998). Nadzorować i karać. Narodziny więzienia. Warszawa: Fundacja Aletheia.

Godziński, B. (2018, 13 maja). Skrajna prawica kopiuje styl życia od lewicy. Czy nacjonalista może być straight edge? https://natemat.p1/237847,prawicowystraight-edge-czy-nacjonalista-moze-byc-sxe.

Good, L.K., Huddleston P. (1995). Ethnocentrism of Polish and Russian Consumers: Are Feelings and Intentions Related. International Marketing Review, 12 (5), 35-48.

Gow, P. (1989). The Perverse Child. Desire in a Native Amazonian Subsistence Economy. Man (N.S.), 24 (4): 567-582.

Haenfler, R. (2006). Hardcore Punk, Clean Living Youth, and Social Change. New Brunswick, New Jersey, and London: Rutgers University Press.

Harris, M. (1985). Meat Hunger. W: M. Harris, Good to Eat: Riddles of Food and Culture (s. 19-46). New York: Simon and Schuster. 
Herdt, G.H. (1984). Semen Transactions in Sambia Culture. W: G.H. Herdt (red.), Ritualized Homosexuality in Melanesia (ss. 167-210). Berkeley: University of California Press.

Kitowicz, J. (1840). Opis obyczajów i zwyczajów za panowania Augusta III. Poznań: Edward Raczyński.

Kleśta-Nawrocka, A. (2016). Kucharz doskonaty. Historyczno-kulturowy fenomen kuchni staropolskiej. Toruń: Polskie Towarzystwo Historyczne.

Kuhn, G. (red.) (2010). Sober Living for the Revolution: Hardcore Punk, Straight Edge, and Radical Politics. Oakland: PM Press

Kürti, L. (2012). Twenty Years After Rock. Music and National Rock in Hungary. REGION: Regional Studies of Russia, Eastern Europe, and Central Asia, 1(1), 93-129.

Lesiv, M. (2013). The Return of Ancestral Gods: Modern Ukrainian Paganism as an Alternative Vision for a Nation. Montreal \& Kingston, London, Ithaca: McGill-Queen's University Press.

Likhachev, V. (2013). Right-Wing Extremism on the Rise in Ukraine. Russian Politics \& Law, 51 (5), 59-74.

Maurer, D. (2002). Vegetarianism. Movement or Moment? Philadelphia: Temple University Press.

Moskalewicz, J., Zieliński A. (1995) Poland. W: D.B. Heath (red.), International Handbook on Alcohol and Culture (ss. 224-236). London: Greenwood.

Okraska R. (2001). W kręgu Odyna i Trygława. Biała Podlaska: Rekonkwista.

Parasecoli, F. (2005). Feeding Hard Bodies: Food and Masculinities in Men's Fitness Magazines. Food \& Foodways, 13, 17-37.

Petrusevičiūtè, A. (2010). The Construction of Pagan Identity in Lithuanian "Pagan Metal" Culture. Praca magisterska. Kaunas: Vytautas Magnus University.

Potrzebowski, S. (2016). Słowiański ruch Zadruga. Szczecin: Triglav.

Rival, L. (1998). Androgynous Parents and Guest Children: The Huaorani Couvade. The Journal of the Royal Anthropological Institute, 4 (4), 619-642.

Shekhovtsov, A. (2012). European Far-Right Music and Its Enemies. W: R. Wodak, J.E. Richardson (red.), Analyzing Fascist Discourse: European Fascism in Talk and Text (s. 277-296). London: Routledge.

Shizhenskiy, R. (2017). The Role of Food in Contemporary Russian Paganism. W: A. Anczyk, J. Malita-Król (red.), Walking the Old Ways in a New World. Contemporary Paganism as Lived Religion (s. 161-181). Katowice: Sacrum Publishing House.

Simpson, S. (2000). Native Faith: Polish Neo-Paganism at the Brink of the 21st Century. Kraków: Nomos. 
Rodzimowierstwo a straight edge: budowanie aryjskiego ducha...

Simpson, S. (2008a). Składnia neopogańskiego rytuału picia w kręgu. Państwo i Spoleczeństwo, 8 (4), 213-223.

Simpson, S. (2008b). Treść, struktura i funkcjonowanie polskiego rytuału picia.

W: I. Borowik, M. Libiszowska-Żółtkowska, J. Doktór (red.), Oblicza religii i religijności (s. 384-397). Kraków: Nomos.

Simpson, S. (2010). History and Mythology of Polish Vodka 1270-2007. Food and History, 8 (1), 121-148.

Simpson, S. (2012). Strategies for Constructing Religious Practice in Polish Rodzimowierstwo. W: A. Anczyk and H. Grzymała-Moszczyńska (red.), Walking the Old Ways: Studies in Contemporary European Paganism (s. 11-36). Katowice: Sacrum Publishing House.

Simpson, S. Filip M. (2013). Selected Words for Modern Pagan and Native Faith Movements in Central and Eastern Europe. W: K. Aitamurto, S. Simpson (red.), Modern Pagan and Native Faith Movements in Central and Eastern Europe (s. 27-43). Durham: Acumen.

Sołtysiak, A. (1999). Blót i Symbel. W: M. Ziółkowski (red.), Antropologia religii. Wybór esejów, t. 1 (s. 133-144). Warszawa: Zakład Antropologii Historycznej. Instytut Archeologii Uniwersytetu Warszawskiego.

Strutyński, M. (2005). Pogański narodowy socjalizm w Polsce współczesnej. W: Z. Pasek (red.), Ezoteryzm, okultyzm, satanizm w Polsce (s. 157-179). Kraków: Libron.

Strutyński, M. (2008). Zakon Zadrugi Północny Wilk. Niektóre inspiracje ideowe współczesnego polskiego neopogaństwa. W: P. Wiench (red.), Przeszłość i tożsamość: Społeczno-kulturowe aspekty polskiego neopogaństwa (s. 73-84). Warszawa: Wydawnictwo SGGW.

Tupešu, J. (1987). The Ancient Latvian Religion. LITUANUS: Lithuanian Quarterly Journal of Arts and Sciences, 33 (3), 46-61. http://www.lituanus. org/1987/87_3_06.htm.

Turner, B.S. (1982). The Discourse of Diet. Theory, Culture \& Society, 1 (1), 23-32.

Widdicombe, S. (1998). “But You Don't Class Yourself”: The Interactional Management of Category Membership and Non-Membership. W: C. Antaki, S. Widdicombe (red.), Identities in Talk (s. 52-70). London: Sage.

Williams, J.P., Copes H. (2005). How Edge Are You? Constructing Authentic Identities and Subcultural Boundaries in a Straightedge Internet Forum. Symbolic Interaction, 28 (1), 67-89.

Wood, R.T. (1999). 'Nailed to the X': A Lyrical History of the Straightedge Youth Subculture. Journal of Youth Studies, 2 (2), 133-151. 